\title{
WOMEN'S EMPOWERMENT THROUGH CANVAS BUSINESS MODEL
}

\author{
Ida Hindarsah \\ Business Administration Department, Universitas Pasundan
}

Ida.hindarsah@unpas.ac.id

\begin{abstract}
Increasing population in a country, especially in developing countries, has an impact on various aspects, one of them is social impact. The emergence of criminality, acts of violence, sexual harassment is phenomenon which is part of a development, including violence against women who experienced a significant increase. This condition raises high fears so that one way is equipped with self-defense (martial arts). This study aims to comprehensively review women empowerment through the approach of canvas business model. The research method used is qualitative. Data analysis techniques using the steps of reduction, data presentation, conclusion / verification. Testing the validity of data is done through credibility, perseverance, triangulation, feedback / feedback, member check. The result of this research is the existence of Canvas business model on the empowerment of women, this model is made in an effort to develop the existence of WSDK community in the future, in this research also known constraints in the empowerment of women through the approach of canvas business model and describe efforts to anticipate these constraints.
\end{abstract}

Key words: Women empowerment, canvas business model.

\section{Introduction}

Based on the preamble of the 1945 Constitution "which states that freedom is the right of all nations. Therefore all forms of colonialism. This colonial phenomenon is not only for a country only but personally it is absolutely free of all people regardless of gender status with other terms of gender equality. Kartini is one of the symbols of women's freedom on Indonesian soil, he strives to equate rights with men. The contribution of women is as important as men in building a country including the establishment and liberation of a nation. This phenomenon can be seen by the fall of the heroes of women who died in realizing the nation's independence.

In Indonesia the empowerment of women or who we know of women's emancipation in its history is seen in the Indonesian Women's Congress I in Yogyakarta, at the end of 1928. The existence of this congress is an attempt to address unilateraland unilateral treatment for women. The expected result of this congress is a change in all aspects including social, political, cultural, legal. The government gives serious attention to the women, it can be seen from its progender policies and in line with the millennium development goals such as the enactment of Law no. 5 of 1990, concerning Inpres Desa Tertinggal (IDT) Program for community economic development and IDT program followed by P3DT of Ministry of Public Works, for rural infrastructure activities. For the next generation of PKK activities through the Ministry of Home Affairs that collaborate both activities (economy and infrastructure) and for similar programs for urban programs under the name of P2KP. This spirit of empowerment inculcates the values of modern culture, such as hard working, self reliance, efficiency, open mind, and responsible attitude are central to this empowerment 
effort. Some of the goals of women's empowerment are as follows:

1. Because women have a common interest in development, and are also users of development outcomes, who have equal rights with men.

2. Women also have special interests for women themselves and children. The less optimal if initiated by men because it requires a special sensitivity, associated with daily, socio cultural.

3. Empowering and involving women in development, indirectly will also empower and transmit the positive spirit to the next generation, which in general in everyday very closely with mother figure.

(www.pnpmmandiri.com pemberdayaan perempuan)

Some of Bandung's strategic issues are population quantity control, population quality development, gender mainstreaming (PUG) development and child protection development. In addition, there are still some other issues and the following are: the low understanding and awareness of women and the community in general about gender equality and justice, so that women's participation in decision making in various sectors is still included in their involvement in economic empowerment. This phenomenon is not only a peer for the government but also individuals and all people who care about women one of them is a community of women who joined in the field of self-defense is WSDK (Women Self Defense Kopo Ryuku). WSDK was founded in 2006 by Mr. H. Sofyan Hambally, a martial arts expert karate and ju jitsu from the city Kopo Bandung.

Departing from the concerns of women who at the time of re-establishment of violence against women and tragic to the murder of two students who dumped into the river, this became a shocking and alarming news given the surrounding environment. Therefore
WSDK stands to contribute to the community about the importance of maintaining themselves early in order to avoid unwanted violence and criminal acts. The motto made by WSDK is gentle does not mean weakness in the softness of stored strength.

Members of this WSDK come from various backgrounds and professions, the interesting thing about this community is that there are some of the women who are victims of violence from families, households and the environment. Aktvitas WSDK develop not only on the side of physical coaching but also mentally and even grow to the strengthening of the economy because with a strong mental and economic make easy position of women can not be underestimated easily. Therefore, the existence of WSDK becomes an important part to reduce violence and can contribute in strengthening the economy, but in reality the existence of this community has not run as expected considering the competition between similar communities are emerging, therefore need a strategy to maintain and develop the existence of this WSDK. In this research, the researchers looked from the perspective of the business model, the concept of business model began to be widely used as a common way to explain how companies interact with suppliers, partners, and customers (Zott and Amit: 2011).

One business model currently under development is Business Model Canvas. Business Model Canvas (BMC) is one of the strategic tools used to describe a business model and illustrates the basis of thinking about how organizations create, deliver, and capture value. Business Model Canvas is a tool to help us see more accurately the kind of business that we are or will be living. Converting a complex business concept into a simple one is displayed on a single sheet of canvas containing a business plan with nine key elements that integrate well within it including 
internal and external corporate strategy analysis (Osterwalder and Pigneur: 2012).

At the time of mapping a business using Business Model Canvas, then used nine basic building blocks. Osterwalder and Pigneur (2012), said that business models can be explained very well through nine basic building blocks that show how to think about how companies make money. Nine blocks of the building are placed on an arrangement called Business Model Canvas. Business Model Canvas is divided into nine main blocks; Customer Segmentation, Value Proposition, Channel, Customer Relationship, Revenue Streem, Key Resources (Key Resources), Key Activity (Key Activity), Key Partnership (Main Partnership), and Cost Structure (Cost Structure). Then these sections will be divided again on two sides of the left side (logic) and the right side (creativity).

Based on the explorations that researchers do during the field found some of the problems include:

1. Customer segment: overall they have not been able to map specifically which is the arable territory that entered the niece market.

2. Channel: not yet maximally using channel, but not yet able to determine the effectiveness of this channel.

3. Customer relationship: still rely on trust relationship between partner with WSDK community.

4. Revenue streams: overall they only rely on the results of registration only.

5. Key Resourcess: the limited organizational resources both from human resources, facilities and infrastructure, income and strategies undertaken.

6. Key parnership: limited accessibility.

7. Cost structure: limitations in determining and sorting costs.

Based on these problems then needed a strategy for this community can survive and can win the competition. Therefore need to do the strategic and tactical steps of each of these components by using Business Model Canvas. which is the business model Busniness Model Canvas is a business strategy that describes, visualize, assess, and change the business model within a company that allows the company to know the condition of the company, evaluate the state of its market position and then adjust it to current market conditions. This thorough examination can be the basis for a gradual improvement of the business model and the researcher pours this research with the title: Empowering women through the Canvas Business model (case study on WSDK in Bandung).

\section{Theoritical Framework}

One of the successes of a nation can be seen from its economic activity and community involvement becomes the main thing in the acceleration of economy as well as the role of women is quite high considering the composition of the population in Indonesia the number of women more than men. Nevertheless the role of women in economic empowerment is still relatively left behind so that the need to do empowerment, to empower women economy need to be done not only individual but also group or community. Empowerment is essentially a means of empowerment or empowerment improvement. Community empowerment can be interpreted as an effort to encourage the community to be able to participate actively in all aspects of development. Sulistiyani (2004) explains, that Etymologically empowerment comes from the word power which means strength or ability. Based on the definition, empowerment is defined as a process to gain power, strength or ability, and / or the provision of power, strength or ability of the party having power to the less or less powerful. Meanwhile, according to Prijono, S. Onny and Pranarka, AMW 
(1996), empowerment is a process to the community to be empowered, encouraging or motivating individuals to have the ability or empowerment to determine their choice of life and empowerment should be aimed at groups or layers of disadvantaged communities.

In the context of women's empowerment, according to Nursahbani Katjasungkana in the discussion of the National Strategy Development Strategy Team (Riant Nugroho:2008) argues, there are four indicators of empowerment.

1. Access, in the sense of equal rights in accessing productive resources within the environment.

2. Participation, ie participation in utilizing the limited assets or resources.

3. Control, namely that men and women have equal opportunity to exercise control over the utilization of these resources.

4. The benefit, that both men and women should share the benefits of shared or equal use of resources or development.

Professor Gunawan Sumodiningrat quoted Riant Nugroho (2008) explains, to empower need three steps continuous.

1. Appeasement, meaning that women as an empowered party should be bullied rather than male.

2. Preparation, meaning empowerment requires the ability of women to be able to access, participate, control, and benefit.

3. Protection, meaning to provide protection until it can be removed.

Therefore, the empowerment program for women in the economic field is very necessary because basically women have tremendous potential in the economy especially in the economic setting of the household. In the field of economy, women empowerment is more emphasized to improve the ability to manage the business, especially in this case is the home industry business. There are five important steps to be taken into account in the development of entrepreneurship skills for women. According to the IMF cited by Herri, et al (2009) the five steps are:

1. Assist and encourage women to develop and develop their own knowledge and competence through various training programs,

2. Aasist women in business strategy and product marketing,

3. Provide understanding on government regulations and regulations related to the legality of the business world,

4. Encourage and assist women to be able to use information and communication technology optimally,

5. Create Micro Business / Micro Women Business Network / Business Training Forum.

\section{Women Empowerment Strategy}

In the 70s decade of awareness about the role of women began to evolve that was manifested in the direction of the program approach that focused on the problem of Women in Development. This is based on a notion of the need for independence for poor women so that development can be enjoyed by all parties. The emergence of women in development (WID) thinking because women is a valuable human resource so that its marginalized position needs to be incorporated into development .

The WID approach pays attention to the productive role of women in development. The purpose of this approach is to emphasize on the productivity side of female labor, particularly with regard to women's incomes, without being too concerned about the reproductive side. While the target is poor women economically poor. liberals from the West are deeply affected by this WID approach. At that time the existing projects are working hard to improve women's access, especially for poor women to increase 
their income. Increase the income of women for example through skill activities, such as sewing, embroidery and so on (Riant Nugroho:2008).

In realization the WID concept fails to include women in the decision-making process of a development project, hence the concept of Gender and Development (GAD) as its follow-up (2008). This concept is based more on an approach to the importance of involvement of women and men in the development process. This approach focuses more on gender issues and is not visible on women's issues alone. The GAD approach is the only approach to women in development by looking at all aspects of women's lives and all work done by women in productive, reproductive, private and public work and rejecting any attempt to assess the low work of maintaining families and households. This approach is known as empowerment.

According to Julia Cleves empowerment is more emphasis on bottom-up empowerment strategy than top-down empowerment (Julia Cleves Moss:1996). Empowerment becomes an important strategy in increasing the role and opportunity of women in improving their economy and is an effort to increase and actualize their potential to be more capable and independent. Empowerment can be done through coaching and skill enhancement.

\section{Business Model}

The development of business can certainly happen from the time of Socrates to Marx, change is an unavoidable problem. But in those days the change is in a definite and measurable environment. Now business leaders have to deal with changes in vague conditions such as geography, time, language, market, private and public (Sawiddji Widiatmojo:2005).

Based on the environmental phenomenon, the question is how will it affect the business world? According to Sawiddji Widiatmojo (2005) there are seven things that will lead to the birth of a new business model: first, the decline of the role of government, especially in the field of economy. Second, the business is the aggressiveness of computer hardware and software industrialist innovation that pushes consumers toward internet usage in business force other industrialists including consumers follow this new way of doing business.

Third, biotech after the internet gets the peak that simplifies the workings, the biotech era soon replaces. Fourth, network is faster, the fifth direct relationship of producers and consumers. Sixth presence of the seventh futuristic product life easier and relaxed. Therefore, in order for the company to survive it needs to be done changes in leadership, managerial and technical aspects so that appropriate business modeling is needed that can illustrate how the organization creates, delivers and captures value (Alexander Osterwalder \& Yves Pigneur:2010), this is in line with the opinion of Cristian Nielson, Morten Lund (2013) which states that a business model is a suistanable way of doing business. Here is the fact that the business model becomes important for a company like that quoted from Henry Chesbourgh (2013) business models are not only important they are crucial. In the most basic sense, a business model is the method of doing business by which a company can sustain itself that is, generate renemue. The business model model has become a topic of discussion both among practitioners and academics so that there has been a different perception and understanding in implementing the model theory business.

\section{Business Model Canvas}

Keep in mind that a business model is a platform as a strategic tool for a company to make a profit, it can be clear 
that the business model is not just talking about pricing strategy, a new distribution channel, an information technology but a quality control scheme for production activities, business is not only value-oriented but on the value proposition so that the overall elements of the business model are interrelated and comprehensive. According to Affuah Tucci cited by Hans Dieter Zimmeemann (2015) says that the components in the business model are as follows:

1. Customer value (what)

a. Differentation Product features, timing, location, service, product mix, linkage between fuctions, linkage with other firms, reputation.

b. Low cost.

2. Scope (to whom, where)

a. Market segments.

b. Geographic areas.

c. Number of product version.

3. Pricing

Types of pricing: menue, one

to one, auction, reverse auction, barter.

4. Revenue source

e.q. in mobile commerce: airtime, volume, content, subscription.

5. Connected activities

Value chain/web perspective: necessary additional activities to create customer value.

6. Implementation
a. Structure
b. Systems
c. People

7. Capabilities
a. Resources
b. Competencies
c. Competitive advantage

8. Sustanaibility
a. Block strategy Erecting barriers around product market space: e.q. limit access to unique and distinctive capabilities
b. Run strategy

Reinventing the business model, being ahead of the competition.

c. Team up strategy

Strategic alliance, joint venture, acquistion, etc

9. Cost structure

a. Understanding the determinats of costs

b. Cost drivers: economies of scale, input to output transformation technology, capacity utilixation, transaction costs.

\section{Methodology}

Qualitative research methods can be interpreted as a research method based on postpositivism / enterpretive philosophy, used to examine the condition of natural objects (as opposed to experiments) in which the researcher as a key instrument, data collection techniques are done by triangulation (combined), data analysis is inductive / qualitative and qualitative results emphasize the meaning of generalization.

The study was conducted on WSDK martial arts community, cibeunying street street No. 8 and Jalan Kopo Citarip Timur No 18 D Bandung, FISIP Campus Pasundan University big lengkong road no 68, Office of DP3AKB West Java Province Ir. H.Djuanda No 250 Bandung.

In qualitative research that becomes instrument or research tool is the researcher itself. Therefore, the researcher as an instrument must also be validated to what extent qualitative researchers are ready to undertake further research into the field. Validation of the researcher as an instrument includes validation of the understanding of qualitative research methods, insight mastery of the field studied, the readiness of researchers to enter the object of research, both academically and logistic, the validation is the researchers themselves, through self- 
evaluation how far the understanding of qualitative methods, theory and insight into the field under study and readiness to enter the field. Qualitative researchers as human instruments function to set the focus of research, selecting informants as data sources, collecting data, assessing the quality of data, analyzing data, interpreting data and making conclusions on it (Sugiyono:2013).

In this research, the sampling is not only in humans but also in the setting and the process. The following will be the researchers describe the population of the three categories are as follows: First, Human: Owner of WSDK dojo in Jalan Kopo Citarip Timur No. 18 D Bandungberdiri from 2006, with no view of educational background. Second, Setting: at the training location in the street of cibeunying and park, academicians and non academics when speaking, writing, communicating personally, communicating official with academic and non academic themes etc. Third, Genesis and process: discussion, writing papers, proposing and rejecting proposals. (Al Wasilah:2013).

In this study the data collection techniques implemented are First: observations as proposed by Susan Stainback (1988) which states that in participant observation, the reserator observes what people do, listen to what they say and participates in their activities. In this research I participated in participative observation in some activities but not all of them. In this observation I undertake the following activities: (1) I observe the founders of the WSDK dojo as the object of research, which at this stage I have not brought the problem to be researched and I conduct a general and thorough exploration and conduct a description of all views, (2) my next visit to make a narrow observation to focus on a particular aspect of business model (3) I do further observation by describing the focus of business model in this stage I have found the characteristics, similarities and differences of the categories and find relationships between one category and another. Both surveys or questionnaires are the most widely used data collection techniques in descriptive research because this study describes characteristics or characteristics of groups, events or phenomena. Descriptive techniques are commonly used to measure three things (1) the existence and distribution of various behaviors or characteristics occurring lamai (2) the frequency of occurrence of naturally occurring events (3) the relationship and the magnitude of possible relationships between characteristics, behavior, events or phenomena yag the researchers concerned (Al Chaedar:2013). In this research survey conducted to the founders, coaches, participants and candidates place.

This survey is conducted to determine the extent to which the business model is applied to the WSDK Community. The third Interview Estbergh (2002) defines the interview as follows: a meeting of two persons to exchane information and ideas through qustion and responses, resulting in communication and joint construction of meaning about a particular topic. Interview is a meeting of two people to exchange information and ideas malalui question and answer, so that can dikontruksikan meaning in a particular topic. In this study I conducted the following interviews:

1. Structured by preparing first what information will be obtained with the research instrument in the form of written questions which alternative answers have been prepared.

2. Semi structured interviews: unstructured interviews, I conducted this interview at the beginning of the study and did not use interview guidelines. the things that I ask is the outline only because I want to get information from various issues or problems that exist at the moment, the interviews were conducted randomly not only to the founders, 
but I do interviews to trainers, participants and prospective trainers to get a full picture of the actual conditions.

In my research done several stages, namely:

1. Data Reduction (Data Reduction) that is by summarizing, choosing the main things, focus on the things that are important with the theme and pattern of them Coding: in this research I do the coding for analyze all data obtained in each stage. In this research I made interview transcripts, observation pabduan notes, field notes and questionnaires with certain codes: such as KOMPEx: Communication with Expert, KOMPEN: Communication with founder, KOMPEL: Communication with trainer, KOMPes: Communication with participants, KOMProv: Communication with Head of West Java Provincial Office. KOMStruk: Communication with structural officials with Vice Chairman of KONI West Java.

2. Presentation of Data (Data Display) In this research, the data presented in the form of tables, graphs, diagrams to facilitate the meaning in this study. With the simplifying function of the complex becomes simple, summarizes the intrepretation of data researchers and presents the data so that it appears thoroughly (Al Chaedar:2013).

3. Conclusion and verification. The initial conclusion is still temporary and will change if there is no strong evidence to support at the next data collection stage. But if the conclusions raised in the initial stages are supported by valid and consistent evidence when the researcher returns to the field to collect the data, the conclusion put forward is a credible conclusion (Miles and Huberman in Sugiyono :2015).
Testing the validity of the data in this study includes the first test of credibility, in this study researches made a repeated observation or with another term extension of observation, I conducted a re-interview with the data sources I have encountered that is the founder of WSDK community and partly with the trainer, participants and prospective trainers with the hope that what we need really can be fulfilled so that the data obtained can be more optimal and the emotional relationships that are interwoven can be more closely it is important for me that they can be more open about many things, especially related to the research topic.

Perseverance, in this research will made various efforts to made the data credible and can be accounted. The things done by me is by reading various references that have to do with research findings such as books, journals, other documentation other supports and triagulation.

\section{Result and Discussion}

\subsection{Existing condition of women empowerment}

Since the enactment of the Convention on The Elimination of All Forms of Discrimination against Women became Law no. 7 of 1984 and Convention on the Rights of Child became Presidential Decree no. 36 of 1990 As a tool, gender analysis involves a strategic empowerment step, to change the condition of women who get worse for the better (justice and gender equality). Accordingly, in the international community, especially in developing countries, there is a development of thinking from women in development (women in development), women and development to gender in development (gender and development). Therefore, development is not only about infrastructure but also related to education, health, employment as stated in Human Development Index (HDI) is 
not enough without Gender Development Index (GDI) and Gender Empowerment Measure (GEM). This is the challenge of current development.

In this development, Inpres was born 9 of 2000 on Gender Mainstreaming in National Development, based on the consideration to improve the position, role, and quality of women, and realize gender equality and justice in family life, community, nation and state. However, in the implementation of these indicators of development still menyisakkan many problems, especially in women. The many cases of crime, violence, domestic violence, other harassment of women make proof that the protection of women is still limited. Therefore, this condition is not only the peer for the government but the whole society including the individuals.

The existence of WSDK is one of concrete steps to anticipate problems in society. This phenomena as told by one of the founders of WSDK said that membership of WSDK is diverse and among others is background from violence, harassment that cause physical and psychic loss. Conditions experienced will certainly have a traumatic impact for those who experience it so it is trouble for mental.

The role of WSDK here is not only to bring someone to be physically strong but as a mental healer in accordance with the motto of strengthen. Based on the results of interviews with some members said that they feel comfortable joining in this WSDK because the kinship climate is very thick. This is one of the strengths in fostering, developing and strengthening relationships among its members.

\subsection{Implementation of women empowerment}

Connectivity among members made by WSDK as well as families, also WSDK involves direct members to engage in the development of the WSDK community.
The empowerment concept enforced in this community is to provide:

1. Access, in the sense of equal rights in accessing productive resources within the environment. This commuity provides the widest possible access to its members who want to engage and develop WSDK without distinguishing anyone. Considering that the community's need for beldiri is still limited, the WSDK continues to make efforts to expand its wings. Therefore, many cooperation has been done such as with government, schools (kindergarten, elementary, junior high school, high school) and universities, media period (television). Members are given freedom to access cooperation with anyone.

2. Participation, participation in utilizing the limited assets or resources. In relation to WSDK participation, it provides flexibility to its members to participate in all activities undertaken by the WSDK from involvement of members to trainers, speakers, social action, business, engage in trainings (entrepreneurship, public speaking, graphology etc).

3. Control, namely that men and women have equal opportunity to exercise control over the utilization of those resources. As stated previously, WSDK does not distinguish between women and men as long as they have the capability, capacity and capability of each. Therefore they have control over themselves to be able to decide what they will do.

4. The benefit, that both men and women should share the benefits of resources or development together and equally. WSDK in this case is as objective as possible to its members in accordance with their respective roles so that the rights and obligations will be comparable to what has been attempted. 
Overall all four of these factors become obstacles for WSDK because they have not been implemented maximally considering that only a few members really want to involve seriously in developing WSDK community. Whatever the efforts of the WSDK are:

1. Improving the quality of human resources through training programs such as entrepreneurship, public speaking, graphology etc).

2. The involvement of these members in developing the WSDK directly or indirectly can have an impact on increasing family income and this income sharing is highly dependent on the respective roles such as trainers, resource persons, intermediaries, etc). Therefore, it is necessary to provide briefing in both capital and skill form.

3. Increasing productive sectors owned by WSDK members apart from community development such as assisting in the development of each member's business, for example cafe business, coffee, accesories and so on. Therefore WSDK facilitates it through various trainings.

\section{Conclusion}

Women Self Defense of Kopo Ryuku abbreviated as WSDK is a women's martial art created by Mr. H. Sofyam Hambally (a professor of Karate and Jujitsu). This Padepokan was established in Kopo in 2006 which was created with other self-defense concept with easy character, paraktis and exciting. Several WSDK activities from 2006 until now have performed many activities including national and international events, seminars, workshops, talk shows, social activities, entrepreneurial activities and other activities that support competence. Many awards have been achieved both nationally and internationally.

The existence of WSDK is one of concrete steps to anticipate problems in society. This phenomena as told by one of the founders of WSDK said that membership of WSDK is diverse and among others is background from violence, harassment that cause physical and psychic loss. Conditions experienced will certainly have a traumatic impact for those who experience it so it is fatal for mental. The role of WSDK here is not only to bring someone to be physically strong but as a mental healer in accordance with the motto of mutual bring up and strengthen. Based on the results of interviews with some members said that they feel comfortable joining in this WSDK because the kinship climate is very thick. This is one of the strengths in fostering, developing and strengthening relationships among its members.

The WSDK community has implemented women empowerment which includes four things:

1. Access, This commuity provides the widest access for its members who want to engage and develop WSDK without distinguishing anyone.

2. Participation, related to participation of WSDK, gives its members the flexibility to participate in all activities undertaken by WSDK from their involvement from members to trainers, speakers, social action, business, engage in trainings (entrepreneurship, public speaking, graphology, etc).

3. Control, WSDK does not distinguish between women and men as long as have ability, capacity and capability respectively. Therefore they have control over themselves to be able to decide what they will do.

4. Benefit, WSDK in this case is as objective as possible to its members in accordance with their respective roles so that the rights and obligations given will be comparable to what has been attempted.

Due to the limitation of research both from time, data collection process, and technical in the field, the researcher only limits on specific points only relevant to 
this research. These restrictions include: The development of women's community history in West Java, Development and partnership, Concept of women empowerment, Constraints and efforts undertaken for women empowerment which should be studied more deeply in this study, Canvas business model, covering nine components.

Some things that researchers can suggest are as follows: For value peposition elements should quickly apply for a patent with an interesting naming. Customer segmentation should have started working on the upper middle segment and thematic. Customer relationship should better develop the network with the approach on line and work with various communities. Channels and key partners further collaborate with various government and non-government agencies. Key activities should be done other activities that are part of IT-based marketing or recruit admin that specialized in online sales. Key resourcess should be involved people who are competent in the field of design and IT. Cost structure should allocate funds for the design and IT. Should be tested model in order to see the effectiveness of his business

\section{Reference}

Dieter Zimmermann 2004 : The Business Model Perspective, wirtschaft informatic: Munster University.

Hastuti, 2004, Pemberdayaan Petani dan Kelembagaan Lokal dalam Perspektif Gender. Working Paper No. 50 Pusat Penelitian Sosial Ekonomi Pertanian Bogor.

Hayati, Amelia, 2007, "Studi terhadap Pemberdayaan Perempuan dalam Pengembangan UMKM di Kabupaten Garut", disampaikan pada Seminar "Membangun Garut Melalui Sumber Daya Lokal Berpotensi Global", Kerjasama Pemerintah Daerah
Kabupaten Garut dan Lembaga Penelitian UNPAD. Tanggal 11 Desember 2007.

Lawrence W Neuman 2003 : Social Research Methods (Qualitative and Quantitative Approaches), Perason Education Ins.

Nielsen Cristian \& Lund Morten 2013: The Basic of Business Models, 1 st edition Cristian Nielsen \& Morten Lund (Eds) \& BookBoon.

Nielsen Cristian \& Lund Morten 2014: Business Model Design ( Networking, Innovating and Globalizing), 2 st edition Cristian Nielsen \& Morten Lund (Eds) \& BookBoon.

Minztzbergh Henry, 2000 : Stratgy Safari, 1 st: Pearson Education Limited USA

Osterwalder Alexander, 2012: Business Model Generation, Terjemahan, PT Elex Media Komputindo, Jakarta.

Osterwalder, Alexander., Pigneur, Yves. 2009. Business Model Generation.Amsterdam: Self Published.

Spieth, Patrick., Schneckenberg,Berg., Ricart, Joan, E. 2014. Business model innovation - state of the art and future challenges for the field. $R$ \& $D$ Management, 44,3, 2014,pp. 238-245

Suryabrata, Sumadi.1983. Metodologi Penelitian. Jakarta:PT. Raja Grafindo Persada. What is Research Design, Part One, ,Research Methodology, .........

Widoatmodjo Sawidji 2005: New Business Model (Strategi Ampuh Memenangi Bisnis di Abad ke 21), Cetakan Pertama: PT Elex Media Komputindo, Jakarta.

https://majalahkartini.co.id/berita/serbaserbi/komunitas-perempuanbandung

http://www.pikiranrakyat.com/bandungraya/2017/09/29/kemajuan-kota- 
butuh-peran-aktif-perempuan-

$\underline{410498}$

http://www.docstoc.com/docs/2086049

5/ Studi terhadap pemberdayaan

perempuan dalam pengembangan

usaha mikro, kecil dan menengah

(UMKM) di Kabupaten Garut.

http://www.docstoc.com/docs/1970782

0/Program Penanggulangan

Kemiskinan di Kecamatan

Temon, Kulonprogo DI

Yogyakarta.

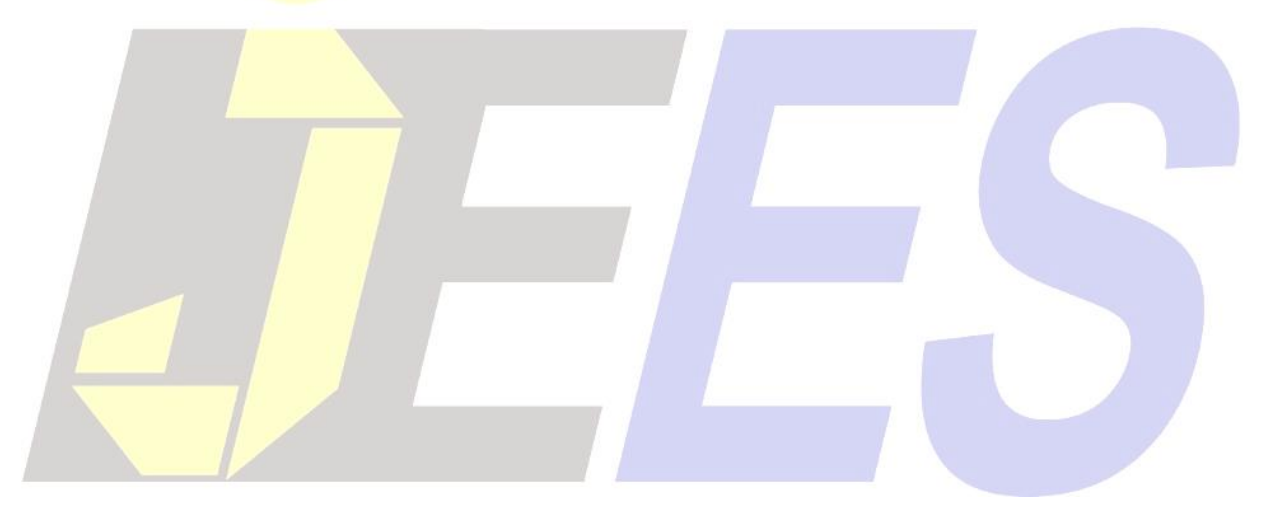

